to-three arrangement, or a four-to-two: and it is quichly found that the last is the only solution possible. Consequently every oxygen atom is at the centre of gravity of its four oxygen neighbours, from each of which it is separated by a hydrogen atom. 'This defines the structure, except that there are two alternatives, corresponding to the two alternative forms of close packing, hexagonal and cubic. 'The former is usual in the case of ice, but apparently the latter has been observed.

Other properties of the erystal have also been examined: Born, Landé, and others have considered the elasticity of the crystal in reference to the unit, especially in the caso of polar crystals, such as rock salt. Older measurements of the physical properties of crystals are applicable now that the structure of the unit can be examined: but the whole field is barely touched as yet. Backhurst, who has inrestigated the effect of temperature, up to $900^{\circ} \mathrm{C}$., on the reflecting powers of crystals has obtained some very interesting results, incidentally, on their behaviour during expansion. A cubic crystal expands uniformly in all directions of course; but the examination of the expansion of the crystal unit in various directions must give important results. For example, Backhurst finds that the expansion of graphite along the axis is very great : whilst across the axis it is small, perhaps no more than in the case of diamond. In the sapphire the effect of temperature upon the intensities shows that the relative arrangement of the molecules changes : the two aluminium atoms keep apparently at the same distance, $2 \cdot 7$ A.U., from each other-they are in a sense in contact -whilst the other atoms move with respect to them. A very interesting lino of research opens up in this way.

Very little, indeed, has been done with respect to optical properties. Astbury has been examining the structure of tartaric acid: he finds that there are two molecules in the unit cell, and as the latter possesses twofold symmetry only, the molecule has no symmetry at all, as might be expected.

When a model is constructed in accordance with the indications of the X-ray analysis, it shows two spirals in each molecule. One of them lies in the carbon atoms at the core of the molecule and might be expected to persist in solution. It implies an optical activity peculiar to the molecule. The other spiral lies in the hydroxyl groups: it is due to the crystalline structure, and would disappear in a dilute solution in which the molecules have become totally independent. Lowry has predicted the existence of two terms in the expression of the optical activity of tartaric acid; the X-rny analysis suggests their origin.

In this short account it has been possible to describe, no more than briefly, the beginnings of what we may hope will be a great develop. ment of scientific research.

\section{THE CHEMIST'S PART IN THERAPEUTIC PROGRESS}

SIR WILLIAM POPE

$T^{n}$

HE daily Press has lately given a good deal of attention to a new chemical material which is supposed to be an absolute specific in cases of sleeping sickness; this interest is well deserved, but it is not clear that sound views on the subject are being placed before the public. It appears that a substance described as "Bacyer 205" has been found more useful than any previously known as a cure for sleeping sickness $(c f . J ., 1922.218 \mathrm{~m})$; as it is very probable that many substances can be made which will effect this cure, no reason exists for doubting the justice of the claim.

So much importance is attached to the ques. tion that it has been thought necessary to send a deputation of German experts to British Central Africa to test the ellicacy of their product and to prove its value. It is probable, and indeed greatly to be hoped, that they will succed. 'The composition and method of manufacture of the substance are, of course, kept secret so that Germany may be enabled to sell it, at a profit, to the British Government. We are furtlier informed by t'he Times of August 25 that the Baeyer works has provided material for use in the Belgian Congo ngainst malaria and the various coast fevers. We are also told that at the meeting of the "Association of Tropical Disenses," held at Hamburg. the statement was made that " Baeyer 205" is the key to tropical Africa, and consequently to all the colonies, and that the German Government must "be required to safeguard this discovery for Germany ; its value is such that any privilege of a share in it granted to other nations must be made conditional upon the restoration to Germany of her colonial empire."

It may be stated at once that no vast effort on the part of any scientific genius is required to produce a cure for sleeping sickness, or, indeed, of malaria, coast diseases, leprosy and many other maladies which make colonisation difficult. During centuries past a certain number of discases have led to such extreme suffering and have proved so resistant to treatment that exaggernted views have been formed concerning the difliculty of finding a radical curo or an infallible preventive. The more mysterious is a discase in its nature and in its mode of attack, and the more horrible it proves in its effects, the more prone is the mind, by a simplo psychological process, to attach dilficulty to the problem of finding a cure or a prophylactic. Not many years ago one of the foremost of English physiologists romarked to mo that ho conceived two eventualities which would justify him in committing suicide : if ho were suffering from cancer or from syphilis. He may retain his opinion with regard to cancer, a disease which we do not yet understand, but he has 
certainly abandoned syphilis as a justification for desperation.

As a result of scientific work of the very highest order of excellence we now know the nature of syphilis; this disease is due to the presence of a minute organism, the Spirochata pallida, in the blood stream, and kincmatograph exhibitions have been given showing the organism at work. The nature of the disease once established no great scicntific genius was required for the production of a cure; a comparatively simple routine method is available for discovering a cure for syphilis and for those many diseases of allied character-malaria, coast diseases, leprosy-which malke colonisation difficult. 'I'his efticient method of attacking the problem has been applied by the Germans ; it consists in studying the toxic effects of all likely chemical substances on the lower organisms which may cause disense by establishing themselves in the blood stream. Ehrlich found that substance numbered 606 is more toxic to the organism of syphilis than it is to its human host; substance 606 then at once took precedence of all other means of treatment and established itself as the first definite cure for syphilis. Similarly it was found that injections with trypan-blue cure piroplasmosis or redwater, which had long been recognised as the scourge of all the great cattle-raising areas of the world. In the same way, if Bacyer 205 destroys the trypanosome before it kills the patient it will cure sleeping sickness.

If we have any faith in the methods of science and repose any confidence in the direct and logical conclusions drawn from experimental results we must believe that each disease of this particular parasitic class-syphilis, malaria, sleeping sickness, leprosy, etc.-can be cured by one application of some one of the myriads of chemical substances which can now be made. This being the caso it seems shameful that this country, with its great overseas responsibilities, should be content to allow Germany, with no colonies, to carry out the simple programme of investigation which leads to the discovery of infallible curativo agents for tropical diseases which are otherwise fatal.

The National Medical Research Council is well organised for studying the properties of any particular drug which may be brought to its notice, but something more than a medical or pharmacological organisation is needed for the efficient working-out of the problems presented. The Government requires a council of chemists capable of drawing up a programmo of work involving the preparation of series of allied compounds which may bo expected to bo toxic towards the lower organisms productive of this particular large class of discases: with means of promptly making theso compounds, and with the facilities already in existence for studying their therapeutic action, our country would quickly tako precedence of Germany in the discovery of curative methods, and would make impossible the ridiculous claims recently put forward at the Hamburg meeting referred to above. The fact that an "Association of Tropical Medicine" exists in Germany, with the main objects of curing diseases which do not occur in German territory, and of drawing a commercial profit by treating those diseases in the territories of Britain and her Allies, is ample condemnation of our method of coping with tropical problems.

Clcarly, what is required is the establishment of an advisory council of chemists to the Government to confer, to draw up a programme, and to see that it is carried out ; the supply of the necessary research materials to the National Medical Research Council would thus bo assured. As has often been pointed out before, such an advisory council would render inestimable service in connexion with the applications of chemical science and technology to many branches of national activity.

\section{MEETINGS OF OTHER SOCIETIES}

\section{INSTITUTION OF RUBBER INDUSTRY}

At the meeting held in the Engineers' Club, London, on September 4, Mr. F. Kaye read a paper on " Rubber Latex in Paper-Making."

Rubber latex is a limpid liquid which contains 30 to 35 per cent. of rubber and is miscible with water in all proportions. Ammonia is an efficient presorvative, the cost being from $1 \frac{1}{1} \mathrm{~d}$. to $2 \mathrm{~d}$. per gallon of latex, and material thus preserved is selling in London at 4s. 3d. per gallon. The cost of breaking down the coagulated rubber used for compounding may be from $\perp 7$ to $£ S$ per ton, and this can be set against the increased freightige on rubber imported in tho form of latex.

Tho method of using rubber latex in papermaking is comparatively simple, the essential condition being extensive dilution of the latex beforo addition to the beaten pulp, so that the Iatex quickly penetrates and becomes intimately associated with every particlo of the beaten fibre. After thorough mixing with the pulp the rubber is thrown out on tho fibre by suitablo coagulativo agents, such as magnesium sulphate or acetic acid. Alum is found, however, in most cases to be effective, used exactly as in ordinary paper-making processes. If the paper has to bo tub-sized alum can to used as the congulativo agent, and if tho paper is machine-sized tho latex may bo added before or after the size and alum, provided that suflicient alum is added to throw out tho sizo and rubber completely.

Rubber latex has some specific effect upon the fibres in the beating ongino and upon the rate of liydration of the fibres. Fibres in paper mado with small or largo amounts of rubber latex are of ten closer and moro uniform in texture than a paper mado of the same fibre without rubber latex. Paper can bo considerably improved by adding such small amounts of latex is will givo a rubber content of $0.1,0.2$, and 0.5 per cent., and regetable, animal, and ovon mineral fibres, such as asbestos, may be used in paper containing rubber latex. New qualities of paper can be made, and if larger proportions 